\title{
OPERATIVE CORRECTION OF JUDOISTS' TRAINING LOADS ON THE BASE OF ON-LINE MONITORING OF HEART BEATS RATE
}

Liu Yong Qiang

Henan Polytechnic University, Republic of China

\begin{abstract}
Purpose: ensure increase of effectiveness of training process's control by means of operative correction of training loads of different qualification judo wrestlers' heart beats rate indicators. Material: the research was conducted on the base of Brest SCJSOR № 1. Judo wrestlers of different sport qualification (age 17-19 years old, n=15) participated in the research. Monitoring of judo wrestlers' heart beats rate was carried out with the help of system "Polar". Results: we have found factorial structure of functional fitness in every profile of sportsmen. Model characteristics of judo wrestlers were supplemented with the most important sides of functional fitness. Analysis of indicators of restoration effectiveness indicators (REI) in both groups of judo wrestlers showed high level of organism's responsiveness to training load of special and power orientation in comparison with speed power load. We have worked out algorithm of operative correction of training loads by indicators of heart beats rate in training process, depending on orientation and intensity of loads' physiological influence on judo wrestler. Conclusions: Telemetric on-line monitoring of sportsman's heart beats rate and calculation of REI permit to objectively assess effectiveness of training's construction and of micro-cycle in total and detect in due time the trend to development of over-loading and failure of adaptation.

Key words: operative control, judo wrestlers, restoration effectiveness indicator, heart beats rate, heart beats rate monitoring, over-load, factorial structure, algorithm, functional fitness.
\end{abstract}

\section{Introduction}

At present in judo there is observed intensification of training process, connected with implementation of new specialized means of training and control over their influence on sportsmen's organisms [1-4].

Modern system of management of judo wrestlers' sport training is based on interconnected functioning of three systems which are in mutual co- submission: purpose of functioning, system of functioning and system of training [4-6]. This combination of application of systemic-structural components is under control and, if necessary, is corrected in general or partially for rendering more substantial impact on prognostic assessment of sport training. In this connection control shall be understood as system of rational measures, based on effective means and methods. In this system means and methods are combined in progressive form of organization of training process in order to achieve prognosticated, planned and expected results.

Complexity of the regarded problem is still more evident, if substantiation of training programs' construction implies not fulfillment of oriented on maximum loads (that is characteristic for the present time) but rather receiving of programmed training effects $[2,7,8]$.

At the same time, advanced experience of judo wrestlers' training witnesses, that excessive training and competition loads result in over-tension of organism's functional systems and increase of traumatism. It can be prevented from by rational construction of training process. It is conditioned by balanced correlation of work of different orientation, dynamic of training loads, alternation of tiredness and rest, means of workability's recreation, mobilization of functional reserves of judo wrestlers $[1,9,10]$. In system of control sportsmen's training important place is assigned to scientifically based control, which implies collection of stage-by-stage, current and operative information about object's condition and comparing of his actual condition with proper $[2,3,11,12]$. With it, role of diagnostics in control system increases, because it permits to create required conditions for operative monitoring of training process and passing of rational adaptation changes in achievement of efficiency and reliability of competition functioning. That is why it is necessary to orient on such indicators, which adequately reflect organism's operative conditions: readiness for fulfillment of certain physical load, speed of recreational processes after trainings, effectiveness of functioning of different physiological systems [13-16].

Besides, in the course of operative control over training activity it is possible to realize the following assessment: sportsman's operative condition (i.e. urgent responses of his organism to loads); express-assessment of sportsman's condition at the moment or just after finishing of exercise. By results of such control it is possible to judge about correspondence of actual training effect with planned effect [7].

Basing on the a.m. we can say that the most informative, integrative and accessible for detection indicators of organism's functional state is heart beats rate (HBR). By its change it is possible to judge about urgent, relayed and cumulative effects of specific training loads [14, 17-19]. That is why control over training loads with monitoring of sportsmen's heart beats rate during fulfillment of different motor tasks by them will permit to achieve more perfect and informative forms of control over work fulfillment. In the future it will facilitate planning of training functioning in general with higher quality.

Thus, the choice of problem of our research was conditioned by actual scientific practical contradiction between existing system of control over different qualification judo wrestlers' training (on the one hand) and insufficient information about practiced training loads and their adequacy to judo wrestlers' individual potentials (on the other hand).

(C) Liu Yong Qiang, 2015

http://dx.doi.org/10.15561/20755279.2015.0203 
It is logical to assume that operative correction of judo wrestlers' training loads by indicators of their heart beats rate with the help of modern mobile telemetric means will be one of necessary components of training process's control during all period of training.

\section{Purpose, tasks of the work, material and methods}

The purpose of the work is to ensure increase of effectiveness of control over training process by means of operative correction of different qualification judo wrestlers' training loads by hear beats rate indicators.

The task of the work: working out of algorithm of operative correction sequence for training loads of different orientation on the basis of heart beats rate monitoring.

The methods and organization of the research:

In the research we used methods of theoretical study, experimental-empiric methods and methods of mathematical statistic. Mathematical processing of statistical parameters was conducted with the help of computer program STATISTIKA 6.0. For monitoring of judo wrestlers' heart beats rate we used multi-channel radio-telemetric system «Polar $400 »$. With its help we corrected and optimized intensity of training on the base of record of HBR indicators in real time.

For determination of judo wrestlers' functional fitness and its dynamic under impact of training loads we used widely spread in practice of sport wrestling control tests [5].

For assessment of different qualification judo wrestlers' functional fitness we applied the following tests:

1. Throw of dummy over hip during 1 minute (special endurance). Description: the tested is in initial position - main stance and holds dummy by hands. By signal the tested shall as quick as possible and technically correctly fulfill throws over hip. Assessment of results: quantity of throws (n), HBR before and after the task and in 4 minutes of rest are registered.

2. 10 throws of dummy over hip (speed-power endurance). Description: the tested is in initial position main stance and holds dummy by hands. By signal the tested shall as quick as possible and technically correctly fulfill throws over hip. Assessment of results: quantity of throws (n), HBR before and after the task and in 4 minutes of rest are registered.

3. Throw of dummy (big weight) over hip during 1 minute (power endurance). Description: the tested is in initial position - main stance and holds dummy by hands. By signal the tested shall as quick as possible and technically correctly fulfill throws over hip. The weight of dummy is selected, considering the mass of the tested. Assessment of results: quantity of throws (n), HBR before and after the task and in 4 minutes of rest are registered.

For assessment of judo wrestlers' functional fitness in test tasks we used method of telemetric pulse metering. It was the simplest way to conduct urgent and current corrections of training session with the help of the so-called restoration effectiveness indicator (REI). This indicator permits to assess in the whole adequacy of load to sport form of sportsman as on the current moment of time.

Calculation of this indicator is conducted by formula (1), in which it is necessary to put values of pulse metering (HBR) just before fulfillment of training task $\left(t_{1}\right)$, after the last main exercise $\left(t_{2}\right)$ and after 4 minutes' rest $\left(t_{3}\right)$. Processing of data was carried out with program Polar ProTrainer 5.0 (рис. 1).

$$
\mathrm{REI}=\left(\mathrm{t}_{2}-\mathrm{t}_{3}\right) /\left(\mathrm{t}_{3}-\mathrm{t}_{1}\right) * 100 \%
$$

Where:

Interpretation of REI depending on value REI $=50-60 \%$ - proper load; REI $<50 \%$ - too high load (tiredness); REI $>60 \%-$ training stimuli are too low.

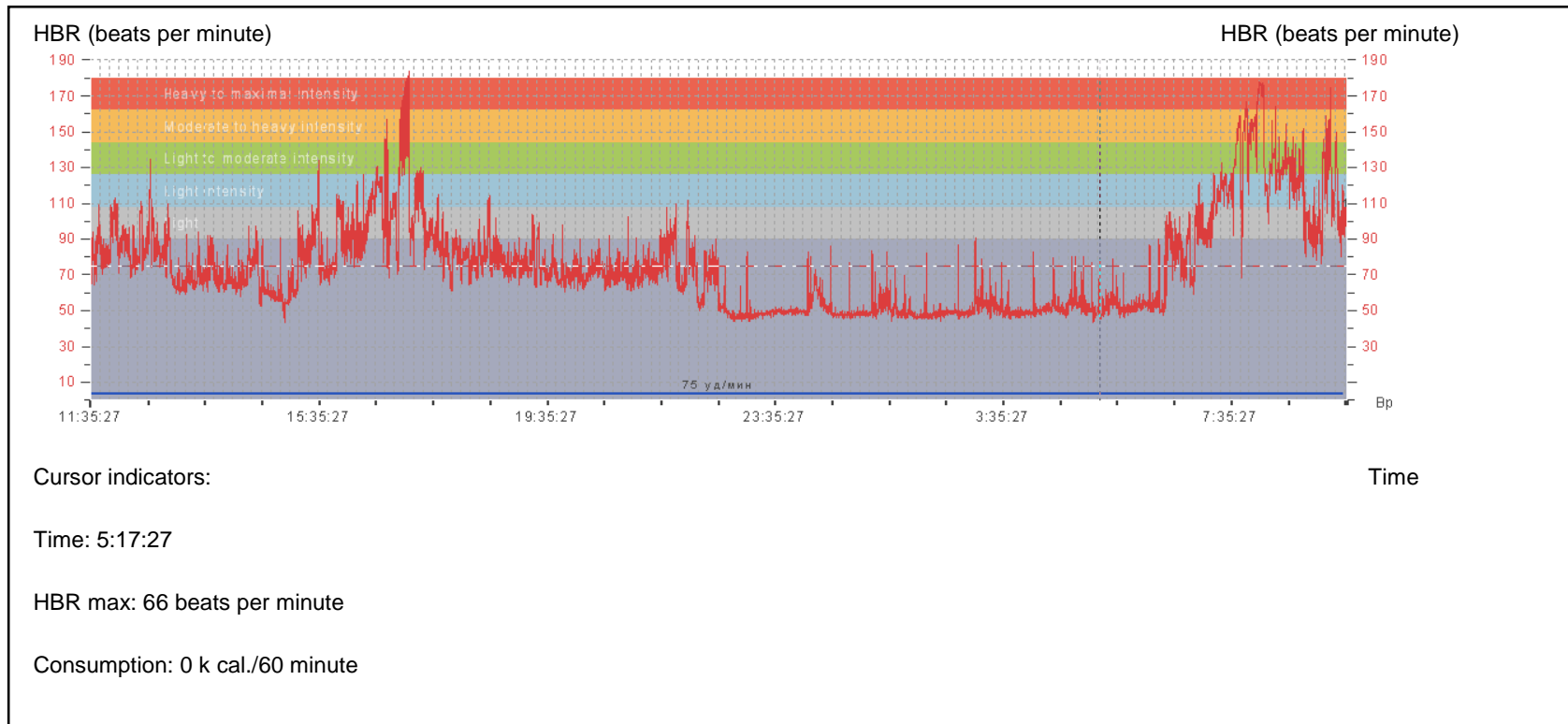

Fig.1. Application of software Polar ProTrainer 5.0. 


\section{Results of the research}

Comparative analysis of functional fitness (see table 1 ) of judo different qualification wrestlers $\left(1^{\text {st }}\right.$ group $-1^{\text {st }}$ grade sportsmen, and $2^{\text {nd }}$ group - candidates master of sports - CMS) permitted to reveal statistically unconfident differences $(\mathrm{P}>0.05)$ between results of tests "throw of dummy over hip during 1 minute" (special endurance: quantity of throws $-\mathrm{t}=0.77$, HBR after the task $-\mathrm{t}=1.72$, HBR after 4 minutes' rest $-\mathrm{t}=0.57$ ); " 10 throws of dummy over hip" (speed-power endurance: time of throws $-\mathrm{t}=1.02$, HBR after the task $-\mathrm{t}=0.14$, HBR after 4 minutes' rest $-\mathrm{t}=1.35$ ); "power endurance, quantity of throws- $t=0,82$, HBR after the task $-\mathrm{t}=1.62$, HBR after 4 minutes' rest $-\mathrm{t}=0.09$ );

Table 1

Comparative analysis of functional fitness of different qualification judo wrestlers

\begin{tabular}{|c|c|c|c|c|c|c|c|c|c|}
\hline \multirow{3}{*}{ Test tasks } & \multirow{3}{*}{ № } & \multirow{3}{*}{ Indicators } & \multicolumn{6}{|c|}{ Finalizing experiment } & \multirow{3}{*}{$\begin{array}{c}\text { Difference } \\
\mathbf{t}\end{array}$} \\
\hline & & & \multicolumn{3}{|c|}{ 1-grade (7) } & \multicolumn{3}{|c|}{ CMS (8) } & \\
\hline & & & M & $\sigma$ & $\pm \mathbf{m}$ & $\mathbf{M}$ & $\sigma$ & $\pm \mathbf{m}$ & \\
\hline throw of & 1 & Quantity of times & 14.14 & 3.39 & 1.28 & 15.50 & 2.29 & 0.87 & 0.77 \\
\hline $\begin{array}{l}\text { dummy over } \\
\text { hip during } 1\end{array}$ & 2 & $\begin{array}{c}\text { HBR after fulfillment } \\
\text { of task }\end{array}$ & 194.57 & 11.93 & 4.51 & 185.25 & 11.86 & 4.48 & 1.72 \\
\hline minute & 3 & HBR after 4 minutes & 149.14 & 24.11 & 9.11 & 144.00 & 13.42 & 5.07 & 0.57 \\
\hline 10 throws of & 1 & Time of throws* & 28.71 & 3.77 & 1.43 & 27.38 & 4.19 & 1.58 & 1.02 \\
\hline $\begin{array}{l}\text { dummy over } \\
\text { hip for }\end{array}$ & 2 & $\begin{array}{c}\text { HBR after fulfillment } \\
\text { of task }\end{array}$ & 170.57 & 16.92 & 6.40 & 169.50 & 15.27 & 5.77 & 0.14 \\
\hline quickness & 3 & HBR after 4 minutes & 119.14 & 7.29 & 2.76 & 124.50 & 6.68 & 2.52 & 1.35 \\
\hline throw of big & 1 & Quantity of times & 10.00 & 2.38 & 0.90 & 11.10 & 2.61 & 0.90 & 0.82 \\
\hline $\begin{array}{l}\text { mass dummy } \\
\text { over hip during }\end{array}$ & 2 & $\begin{array}{c}\text { HBR after fulfillment } \\
\text { of task }\end{array}$ & 200.57 & 11.41 & 4.31 & 195.75 & 11.41 & 4.31 & 1.62 \\
\hline 1 minute & 3 & HBR after 4 minutes & 150.00 & 16.97 & 6.41 & 150.00 & 12.69 & 4.80 & 0.09 \\
\hline
\end{tabular}

In the process of factorial analysis of functional fitness structure of different qualification judo wrestlers we found the following characteristics (see table 2): total contribution in total dispersion of sample (TDS) was $85.33 \%$; in $1^{\text {st }}$ group (of $1^{\text {st }}$ graders) we found 3 factors, total contribution of which was $87.15 \%$; in second group (CMS) we found four factors with contribution in TDS $-83.04 \%$; in $1^{\text {st }}$ group (boys) we found 4 factors with total contribution of $94.18 \%$; and in $2^{\text {nd }}$ group (girls) -3 factors with contribution of $79,87 \%$

Table 2

Factorial structure of functional fitness of different qualification and sex judo wrestlers

\begin{tabular}{|c|l|l|c|c|}
\hline Fact & $\begin{array}{c}\text { Factorial structure of } \\
\text { ors }\end{array}$ & \multicolumn{1}{|c|}{ judo wrestlers } & \multicolumn{1}{|c|}{ Indicators of factors } & Judo wrestlers $(\boldsymbol{n}=15)$ \\
\hline \multicolumn{1}{|c|}{ dispersion } \\
\hline 1 & $\begin{array}{l}\text { Morphological- } \\
\text { physiological features }\end{array}$ & $0.88,0.77$ and 0.82$)$ & 35.08 \\
\hline 2 & Quantitative characteristic & - quantity of throws of dummy (of appropriate mass), of higher mass & 25.17 \\
\hline
\end{tabular}




\begin{tabular}{|c|c|c|c|}
\hline $\begin{array}{l}\text { Fact } \\
\text { ors }\end{array}$ & $\begin{array}{l}\text { Factorial structure of } \\
\text { judo wrestlers }\end{array}$ & Indicators of factors & $\begin{array}{c}\% \text { of } \\
\text { dispersion }\end{array}$ \\
\hline & $\begin{array}{l}\text { of technical tactic actions } \\
\text { (TTA) }\end{array}$ & and time of 10 throws of dummy $(0.81,0.85$ and 0,93$)$ & \\
\hline 3 & Special power endurance & $\begin{array}{l}\text { - HBR after throw of dummy (of proper weight) and (of higher } \\
\text { weight) }(0.90 \text { and } 0.97) \text {. }\end{array}$ & 15.04 \\
\hline 4 & Restoration & $\begin{array}{l}\text { - HBR after } 4 \text { minutes' rest after } 10 \text { throws of dummy with factorial } \\
\text { mass } 0.91\end{array}$ & 10.04 \\
\hline \multicolumn{4}{|c|}{ Judo wrestlers of different qualification } \\
\hline \multicolumn{4}{|c|}{ 1-group (1 graders) $(n=7)$} \\
\hline 1 & Special power endurance & $\begin{array}{l}\text {-quantity of throws of dummy and HBR after throw (of proper mass } \\
\text { dummy) and (big mass dummy); factorial load }(0.81,0.80,0.75 \text { and } \\
0.92)\end{array}$ & 40.28 \\
\hline 2 & $\begin{array}{l}\text { Morphological- } \\
\text { physiological } \\
\text { characteristics }\end{array}$ & $\begin{array}{l}\text {-weight/height indicators, HBR after } 4 \text { minutes' rest after throws (of } \\
\text { proper mass dummy) and (big mass dummy); (0.98, 0.96, } 0.81 \text { and } \\
0.82) \text {, }\end{array}$ & 34.23 \\
\hline 3 & Speed-power endurance & $\begin{array}{l}\text {-time of } 10 \text { throws of dummy, HBR after throw and after } 4 \text { minutes' } \\
\text { rest, factorial load }(0.70,0.72 \text { and } 0.90)\end{array}$ & 12.64 \\
\hline \multicolumn{4}{|c|}{ 2-group $(C M S)(n=8)$} \\
\hline 1 & $\begin{array}{l}\text { Morphological- } \\
\text { physiological } \\
\text { characteristics }\end{array}$ & $\begin{array}{l}\text { - weight/height indicators, HBR after } 4 \text { minutes' rest (accordingly } \\
0.77,0.83 \text { and } 0.72 \text { ) }\end{array}$ & 36.69 \\
\hline 2 & $\begin{array}{l}\text { Quantitative characteristic } \\
\text { of TTA }\end{array}$ & $\begin{array}{l}\text {-quantity of throws of dummy for quickness (of proper mass), (big } \\
\text { mass) and time of } 10 \text { throws (accordingly } 0.91,0.85 \text {, and } 0.83 \text { ), }\end{array}$ & 24.22 \\
\hline 3 & Special power endurance & $\begin{array}{l}\text {-HBR after throw of proper mass dummy and (big mass) (0.96 and } \\
0.97) \text {. }\end{array}$ & 22.14 \\
\hline \multicolumn{4}{|c|}{ Judo wrestlers of different sex } \\
\hline \multicolumn{4}{|c|}{ 1-group (boys) $(n=7)$} \\
\hline 1 & $\begin{array}{l}\text { Morphological- } \\
\text { physiological }\end{array}$ & $\begin{array}{l}\text { - weight/height indicators, HBR after } 4 \text { minutes' rest after throws } \\
\text { (of proper mass dummy) and (big mass dummy); time of } 10 \text { throws }\end{array}$ & 43.07 \\
\hline
\end{tabular}




\begin{tabular}{|c|c|c|c|}
\hline $\begin{array}{l}\text { Fact } \\
\text { ors }\end{array}$ & $\begin{array}{l}\text { Factorial structure of } \\
\text { judo wrestlers }\end{array}$ & Indicators of factors & $\begin{array}{c}\% \text { of } \\
\text { dispersion }\end{array}$ \\
\hline & characteristics & (accordingly $0.80,0.73,0.94,0.97$ and 0.74 ) & \\
\hline 2 & $\begin{array}{l}\text { Quantitative characteristic } \\
\text { of TTA }\end{array}$ & $\begin{array}{l}\text {-quantity of throws for quickness (of proper mass dummy), (of big } \\
\text { mass dummy) with load } 0.92 \text { and } 0.99 \text {, }\end{array}$ & 26.24 \\
\hline 3 & Special power endurance & $\begin{array}{l}\text {-HBR after throw (of proper mass dummy) and (big mass dummy) } \\
\text { with factorial weight } 0.94 \text { and } 0.92 \text {, }\end{array}$ & 15.88 \\
\hline 4 & Functional fitness & - HBR, start $(0,94)$. & 8.99 \\
\hline \multicolumn{4}{|c|}{ 2-group (girls) $(n=8)$} \\
\hline 1 & $\begin{array}{l}\text { Quantitative characteristic } \\
\text { of TTA, considering } \\
\text { weight category }\end{array}$ & $\begin{array}{l}\text { - weight/height indicators, HBR after } 4 \text { minutes' rest after throws } \\
\text { (of proper mass dummy) and (big mass dummy); (accordingly } 0.92 \text {, } \\
0.71 \text { and } 0.80 \text { ) }\end{array}$ & 51,29 \\
\hline 2 & Special power endurance & $\begin{array}{l}\text { - HBR after throw (of proper mass dummy) and (big mass dummy) } \\
\text { with factorial load ( } 0.84 \text { and } 0.76)\end{array}$ & 18,13 \\
\hline 3 & Restoration & - HBR after 4 minutes' rest after 10 throws of dummy $(0,92)$. & 10.45 \\
\hline
\end{tabular}

Factorial structure of functional fitness of different qualification and sex judo wrestlers has its own specificities in quantity of factors and their internal sense, which shall be considered with determination of judo wrestlers' functional fitness for training and competition functioning in certain conditions.

The received factorial structure of functional fitness in any qualification or sex profile permitted for us to supplement model characteristics of judo wrestlers with the most important sides of functional fitness.

In assessment of restoration efficiency indicator (REI) of different qualification and sex judo wrestlers (see fig.2) we registered a number of peculiarities:

- REI in process of "throw of dummy over hip during 1 minute" (of proper weight category and characterizing special endurance) witnesses that organism's response to training load was too high (that can result in tiredness of system) (38.71\%).

- REI in process of "10 throws of dummy over hip for quickness" (of bigger mass and characterizing power endurance) witnesses that organism's response to training load was too high (that can result in tiredness of system) $(52,71 \%)$.

- $\quad$ REI in process of "throws of dummy over hip" (of bigger mass and characterizing power endurance) witnesses that organism's response to training load was too high (that can result in tiredness of system) $(40 \%)$.

Results of REI analysis witness, that for different qualification judo wrestlers training loads are too high in test tasks for special and power endurance. It can result in quick tiredness. In tests for speed-power endurance load was proper. 


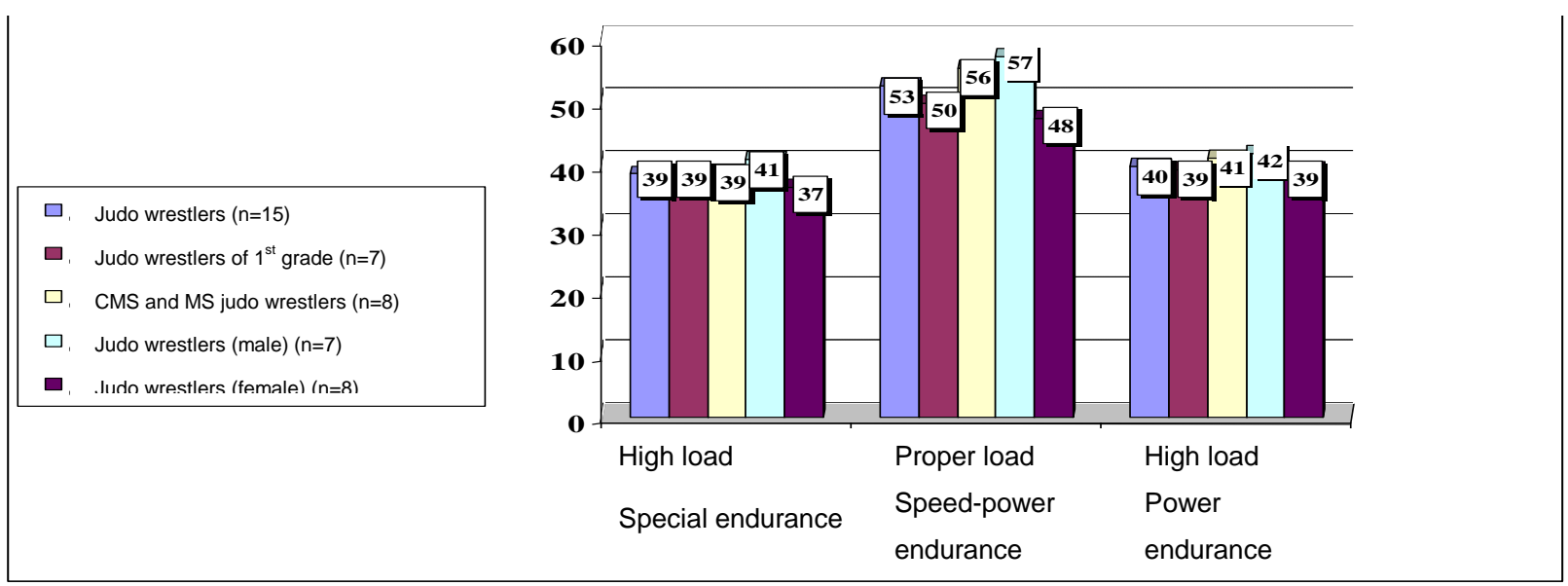

Fig.2. Restoration efficiency indicator of different qualification and sex judo wrestlers, \%

Analysis of boys' REI results witnesses that training load was correct in tests for speed-power endurance. In control tests for special and power endurance load was excessive. It permits to say about tiredness and over-tension under such loads. For girls TEI in all tests was $<50 \%$. It also witnesses about too tensed organism's response to this loads. That is why it is necessary to recommend using in judo wrestlers' trainings REI, with the help of which it would be possible to reliably control parameters of scope and intensity of loads of different orientation.

For detection of signs of incomplete organism's restoration in separate training session we offer to apply the following algorithm of operative correction of differently oriented training loads:

1 STAGE - determination of purpose and task of training;

2 STAGE - determination of initial state of controlled system (by objective and subjective parameters of organism's fitness);

3 STAGE - working out of individual-differentiated program of influences (entering of load parameters by HBR and parameters of load orientation in «Polar»):

\section{- Training exercises by $\mathrm{HBR}$}

- 1 zone - load of low intensity, HBR up to $130-135 \mathrm{bpm}$;

- 2 zone - load of moderate intensity, HBR up to $155-160 \mathrm{bpm}$;

- 3 zone - load of high intensity, HBR up to 175-180 bpm;

- 4 zone - load of maximal intensity, HBR is not considered.

- Loads of purpose orientation

- Aerobic, restorative (140-145 bpm)

- Aerobic developing (up to 160-175bpm)

- Mixed aerobic-anaerobic (up to 180-185bpm);

- Anaerobic hlycolitic (up to $180-200 \mathrm{bpm}$ );

- Anaerobic-alactate (200 bpm and more)

4 STAGE - receiving of information as per definite system of parameters about condition of controlled system (feedback with «Polar») at every moment of control;

5 STAGE - processing of information, received by feedback channel and working out of correcting influences (transfer of information about realization of programmed purpose oriented information on display of "Polar" watch and sound signal);

6 STAGE - realization of correcting influences and plans on the basis of REI calculations (operative corrections are entered in "Polar" for further fulfillment of purpose orientation).

Discussion

As a result of conducted research we have the ground to state that ensuring of effectiveness of training loads' control for different qualification judo wrestlers is possible only with the help of operative registration of heart beats rate indicators. It is proved by researches of other authors [1, 4, 20-23].

In the works of specialists [23-25] functional fitness of judo wrestlers as holistic component are regarded. Just in our research we found factors, which determine structure of judo wrestlers' functional fitness. It permitted to define determinants of functional provision of different structural elements of special motor task, which simulates judo wrestlers' competition functioning.

Many authors $[15,21,23]$ affirm that in connection with intensification of training process there appear still higher requirements to assessment of judo wrestlers' functional potentials with the help of telemetric registration of heart beats rate response to loads of different orientation. In this connection we used restoration efficiency indicator. This indicator permits to assess adequacy of physical load to organism's functional potentials as on current moment of time. On the basis of modern approaches to assessment of judo wrestlers' functional condition we worked out algorithm of operative correction of differently oriented training loads, which consists of six stages. 
The received results are in agreement with researches of other authors [20, 23, 26]. These authors note high response of organism to training load of special and power orientation in contrast to load of speed-power orientation.

All these witness about demand in not only perfection of control system over judo wrestlers' functional state but also in realization of effective control system over training impacts at different stages of sportsmen's training.

Conclusions:

1. Control over training process on the basis of assessment of current training effects with the help of regulation of special exercises by their orientation and intensity of physiological impact on sportsman's organism permits to correct dozing of physical loads. Thus, functional fitness, effectiveness of training process and efficiency of competition functioning significantly improve.

2. Comparative analysis of different qualification and sex judo wrestlers' functional fitness permits to speak about statistically unconfident differences $(\mathrm{P}>0.05)$ of all researched parameters of functional fitness. This fact witnesses about relatively equal level of judo wrestlers' functional fitness, General laws and individual features of functional fitness's factorial model in context of judo wrestlers' motor fitness from the point of system-structural organization of motor functioning.

3. Permanent on-line monitoring of sportsmen's heart beats rate will permit for coach to correct training process during training session or after certain its parts (exercises): vary combinations and sequence of different training means' application; determine quantity of exercises' repetitions and intensity of their fulfillment; rationally determine rest intervals; set correspondence of exercise's intensity to solution of task. Constant recording of heart beats rate and REI calculation permit to objectively assess effectiveness of training micro-cycle's organization, to timely determine the trend to progressing of tiredness or adaptation's failure.

The prospects of further researches imply practical realization of the worked out algorithm of training process's operative correction in different kinds of martial arts.

\section{Conflict of interests}

The author declares absence of any conflict of interests.

\section{References:}

1 Bulatova M.M. Teoretiko-metodicheskie osnovy realizacii funkcional'nykh rezervov sportsmenov $v$ trenirovochnoj $i$ sorevnovatel'noj deiatel'nosti. Dokt. Diss. [Theoretical-methodic principles of realization of sportsmen's functional reserves in training and competitions' functioning. Dokt. Diss.], Kiev, 1996, 50 p.

2 Verkhoshanskij Iu.V. Programmirovanie i organizaciia trenirovochnogo processa [Programming and organization of training process], Moscow, Physical Culture and Sport, 1985, $176 \mathrm{p}$.

3 Godik M.A. Kontrol' trenirovochnykh $i$ sorevnovatel'nykh nagruzok [Control of training and competition loads, Moscow, Physical Culture and Sport, 1980, 136 p.

4 Shiian V.V. Planirovanie trenirovochnykh nagruzok $u$ dziudoistov [Planning of training loads for judo wrestlers]. Sportivnaia bor'ba [Sport wrestling], Moscow, Physical Culture and Sport, 1983, pp. 11-13.

5 Tumanian G.S., Kharacidis S.K. Sovershenstvovanie dziudoistov i sambistov [Perfection of judo and sambo wrestlers]. Teoriia i praktika fizicheskoj kul'tury, 1998, vol.4, pp. 59-61.

6 Little N.G. Physical performance attributes of Junior and Senior women, Juvenile, Junior and senior men judokas. $J$ Sports Med Phys Fitness, 1991, vol.31(4), pp. 510-20.

7 Platonov V.N. Teoriia i metodika sportivnoj trenirovki [Theory and methodic of sport training], Kiev, High School, 1984, 352 p.

8 Shakhmuradov Iu.A., Sukhanov A.D. Programmirovanie sredstv i metodov trenirovochnykh vozdejstvij v sportivnoj bor'be [Programming of means and methods of training influences in sport wrestling]. Aktual'nye problemy sportivnoj bor'by [Urgent problems of sport wrestling], Moscow, FON, 1998, pp. 30-33.

9 Kulikov M., Rybakov V.V., Velikaia E.A. Sportivnaia trenirovka: upravlenie, sistemnost', adaptaciia i zdorov'e [Sportivnaia trenirovka: upravlenie, sistemnost', adaptaciia i zdorov'e], Teoriia i praktika fizicheskoj kul'tury, 1997, vol.7, pp. 26-30.

10 Sterkowicz S, Żuchowicz A, Kubica R: Levels of anaerobic and aerobic capacity indices and results for the special fitness test in judo competitors. Journal of Human Kinetics, 1999, vol.2, pp. 115-135.

11 Nabatnikova M.N. Osnovy upravleniia podgotovkoj iunykh sportsmenov [Principles of control over junior sportsmen's training], Moscow, Physical Culture and Sport, 1982. - 280 p.

12 Ahmaidi S., Portero P., Calmet M. Oxygen uptake and cardiorespiratory responses during selected fighting techniques in judo and kendo. Sports Med. Training and Rehab, 1999, vol.9(2), pp. 129-139.

13 Andreev V.M., Matveeva E.A., Sytnik V.I. Opredelenie intensivnosti trenirovochnoj nagruzki v bor'be dziudo [Determination of intensity of training loads in judo]. Sportivnaia bor'ba [Sport wrestling], Moscow, Physical Culture and Sport, 1974, pp. 13-16. Bulkin V.A. Teoreticheskie koncepcii upravleniia trenirovochnym processom v sporte vysshikh dostizhenij [Theoretical conceptions of control over training process in elite sports]. Tendencii razvitiia sporta vysshikh dostizhenij [Trends of elite sports progressing], Moscow, CNIIS, 1993, pp. 57-62.

14 Iordanskaia F.A. Ocenka special'noj rabotosposobnosti sportsmenov raznykh vidov sporta: diagnostika, mekhanizmy adaptacii, sredstva korrekcii [Assessment of special workability of different kinds of sports' sportsmen: diagnostic, adaptation mechanisms, means of correction], Moscow, Sport, 1993, 291 p.

15 Azevedo P.H.S.M., Drigo A.J., Carvalho M.C.G.A. Determination of judo endurance performance using the Uchi-Komi technique and an adapted lactate minimum test. Journal of Sports Science and Medicine, 2007, vol.6(2), pp. 10-14. 
16 Muramatsu S., Horiyasu T., Sato S.I. The relationship between aerobic capacity and peak power during intermittent anaerobic exercise of judo athletes. Bulletin of the Association for the Scientific Study on Judo Kodokan, 1994, vol.8, pp. $151-160$.

17 Tomlin D.L., Wenger H.A. The relationship between aerobic fitness and recovery from high intensity intermittent exercise. Sports Med, 2001, vol.31(1), pp. 1-11.

18 Volkov N.I. Pul'sovye kriterii energeticheskoj stoimosti uprazhneniia [Pulse energy cost criteria exercise]. Fiziologiia cheloveka, 2003, vol.29(2), pp. 91-97.

19 Kozyreva D.A., Varfolomeeva Z.S. Ocenka funkcional'nogo sostoianiia dziudoistov na etape nachal'noj sportivnoj specializacii [Assessment of judo wrestlers' functional condition at stage of initial specialization]. Sovremennye problemy nauki i obrazovaniia, 2013, vol.6, pp. 390.

20 Zebzeev V.V. Metodika ocenki funkcional'nogo sostoianiia dziudoistov na osnove sistemy kompleksnogo komp'iuternogo issledovaniia fizicheskogo sostoianiia sportsmenov «OMEGA-S2» [Methodic of assessment of judo wrestlers' functional condition on the base of system of sportsmen's complex computer study “OMEGA-C2"]. Kul'tura: vospitanie, obrazovanie, trenirovka, 2009, vol.5, pp. 41-43.

21 Zebzeev V.V. Metodika kontrolia i ocenka funkcional'nogo sostoianiia dziudoistov-iuniorov [Methodic of control and assessment of junior judo wrestlers' functional condition]. Teoriia i praktika fizicheskoj kul'tury, 2012, vol.8, pp. 75-77.

22 Zebzeev V.V. Metody ocenki funkcional'nogo sostoianiia i special'noj vynoslivosti borcov v sovremennom dziudo [Methods of assessment of functional condition and special endurance of wrestlers in modern judo]. Materialy Vserossijskoj nauchno-prakticheskoj konferencii [Materials of All-Russian scientific-practical conference], Kirov, 2014, pp. 223-228.

23 Potapova T.V., Namsrajn A. Funkcional'noe sostoianie iunykh dziudoistov na etape neposredstvennoj podgotovki $\mathrm{k}$ sorevnovaniiam [Functional condition of junior judo wrestlers at stage of direct preparation for competitions]. Vestnik Iuzhno-Ural'skogo gosudarstvennogo universiteta, 2008, vol.4(104), pp. 140-143.

24 Khor'iakov V.A., Mosenz V.A., Perekhrest A.N., Romanenko V.A. Problemy diagnostiki funkcional'nykh sostoianij v sporte [Problemy diagnostiki funkcional'nykh sostoianij v sporte], Fiziceskoe vospitanie studentov tvorcheskikh special'nostej, 2007, vol.4, pp. 89-94.

25 Vershinin M.A., Vershinin, Erofickij A.V., Novikov D.L. Fizicheskaia podgotovka vysokokvalificirovannykh dziudoistov na osnove differencirovannogo podkhoda [Physical training of elite judo wrestlers on the base of differentiated approach]. Fizicheskoe vospitanie i sportivnaia trenirovka, 2014, vol.3(9), pp. 5-10. 
Information about the author:

Liu Yong Qiang: http://orcid.org/0000-0002-4041-9637;
18639118576@163.com; Henan Polytechnic University; Central 18639118576@163.com; Henan Polytechnic Uni

Cite this article as: Liu Yong Qiang. Operative correction of judoists' training loads on the base of on-line monitoring of heart beats rate. Physical education of students, 2015, no.2, pp. 13-21. http://dx.doi. org $/ 10.15561 / 20755279.2015 .0203$

The electronic version of this article is the complete one and can be found online at: http://www.sportpedu.org.ua/html/arhive-e.html

This is an Open Access article distributed under the terms of the Creative Commons Attribution License, which permits unrestricted use, distribution, and reproduction in any medium, provided the original work is properly cited (http:// creativecommons.org/licenses/by/3.0/deed.en).

Received: 09.04.2015

Accepted: 25.04.2015; Published: 30.04.2015 